\title{
Osteosarcoma of the hard palate in a dog - case report
}

\author{
[Osteossarcoma em palato duro de cão - relato de caso] \\ B.L. Silveira ${ }^{1}$, G.D. Cassali², T.C.M. Lopes ${ }^{1,2 *}$ \\ ${ }^{1}$ Universidade Presidente Antônio Carlos - Conselheiro Lafaiete, MG \\ ${ }^{2}$ Instituto de Ciências Biológicas - Universidade Federal de Minas Gerais - Belo Horizonte, MG
}

\begin{abstract}
The osteosarcoma (OSA) is the most diagnosed primary bone cancer in canine patients. This work reports a case of a canine, six years old, mongrel, female, intact, with an OSA in the hard palate. Physical examination detected a firm mass in the palate. Thoracic radiographs, hematological and biochemical exams, histopathological exams and computed tomography were requested. A chondroblastic OSA was diagnosed and the tumor was characterized by immunohistochemistry. There was never evidence of metastasis in this case. The treatment consisted of the combination of conventional chemotherapy, metronomic chemotherapy, and palliative care, aiming at greater survival and well-being of the patient since surgical excision was not possible due to the location and extension of the tumor. Osteogenic sarcomas of the hard palate are rarely seen and described in the literature. In this article we present a characterization of the osteosarcoma with uncommon localization in the hard palate.
\end{abstract}

Keywords: canine, axial skeletal osteosarcoma, hard palate, diagnosis

\section{RESUMO}

O osteossarcoma (OSA) é a neoplasia óssea primária mais diagnosticada em pacientes caninos. Este trabalho relata o caso de um canino, com seis anos de idade, sem raça definida, fêmea, não castrado, apresentando OSA em região de palato duro. Ao exame clínico, constatou-se uma massa de consistência firme em região palatina. Além do exame clínico, foram solicitadas radiografias torácicas, exames hematológicos e bioquímicos, exames histopatológicos e tomografia computadorizada. Fora então dado o diagnóstico de OSA condroblástico, e o tumor foi caracterizado pela imuno-histoquímica. Não foram observadas evidências de metástases nesse caso. O tratamento instituído consistiu na combinação de quimioterapia convencional, quimioterapia metronômica e cuidados paliativos, almejando maior sobrevida e bem-estar do paciente, uma vez que a excisão cirúrgica não foi possivel devido à localização e à extensão do tumor. Neste artigo, apresentou-se uma caracterização do osteossarcoma com localização incomum no palato duro.

Palavras-chave: canino, osteossarcoma em esqueleto axial, palato duro, diagnóstico

\section{INTRODUCTION}

Osteosarcoma is the most common primary bone tumor in dogs. This neoplasia corresponds to $85 \%$ of the malignant bone neoplasms (Kleiner and Silva, 2003). About $25 \%$ of cases of OSA affect the regions of the skull and axial skeleton (Heyman et al., 1992). OSA is an osteogenic sarcoma with fast growth, characterized by invasive and aggressive behavior, and highly metastatic. This malignant neoplasm leads to impairment of bone formation or mesenchymal tissue, with consequent production of osteoid matrix, which differentiates it from other neoplasms (Bane et al., 1990). The diagnosis of OSA is complex and based on anamnesis and detailed clinical examination.

Recebido em 12 de junho de 2020

Aceito em 14 de outubro de 2020

*Autor para correspondência (corresponding author)

E-mail: tamy.moreira@hotmail.com 
Histopathological analysis and immunohistochemistry technique are used to confirm the diagnosis and to determine the histological features of the tumor. Complementary tests such as radiography, computed tomography (CT), magnetic resonance imaging (MRI) and bone scintigraphy have been performed to assess the local extent of OSA (Wittig et al., 2002).

The prognosis of this malignant neoplasm is considered unfavorable, mainly in the presence of lung metastasis (Wittig et al., 2002). Patients with axial skeleton OSA usually die due to secondary disorders associated with the primary tumor or by euthanasia, at the owner's option (Heyman et al., 1992). There are few reports in the literature of OSA of the hard palate (Beck and Strizek, 1999; Diamond et al., 1980; Howard et al., 1976). Therefore, the aim of this work is to report a clinical case of OSA in the hard palate and to review the most important aspects of this neoplasm in axial skeleton, focusing on the diagnosis.

\section{CASE REPORT}

A six-year-old, female, intact dog of undefined breed previously diagnosed with cardiovascular pathology presented difficulty breathing, without impaired appetite. Clinical examination revealed overweight, dyspnea, epistaxis, normohydrate, normothermic, submandibular lymph nodes slightly enlarged, and cardiac auscultation revealing heart disease. On examination of the oral cavity an increase of volume was observed in the center of the hard palate.

Firstly, laboratory exams including complete blood count and serum biochemical analyses were requested in order to assess the patient's health. Hematology (red blood cell count and packed cell volume) values were within the normal limits. The differential white blood cell count showed slight neutrophilia, with increased segmented neutrophils, and a slight reduction in the number of monocytes. Serum biochemical analysis indicated an increase in alkaline phosphatase (290 $\mathrm{U} / \mathrm{L}$, reference interval 20 - $156 \mathrm{U} / \mathrm{L})$. Based on the clinical suspicion of sinusitis and even before obtaining the results of the requested exams, antibiotic and steroidal anti-inflammatory were prescribed. Moreover, the use of saline in both nostrils was recommended.

The patient returned after ten days showing hoarseness, besides dyspnea and nasal discharge. A clinical reassessment was carried out and a more pronounced mass in the oral cavity was observed than previously seen (Figure 1). The CT scan was requested to assess the mass and its extension in more detail. Computed tomography revealed regions of mineralization in the hard palate, of probable bone origin, suggesting neoplasm, with secondary rhinosinusitis (Figure 2). Due to these findings, radiographs of the chest were requested to assess possible lung metastasis and cardiovascular evaluation, as well as to check for bone changes. The radiographic examination did not show the presence of metastasis (Figure 3).
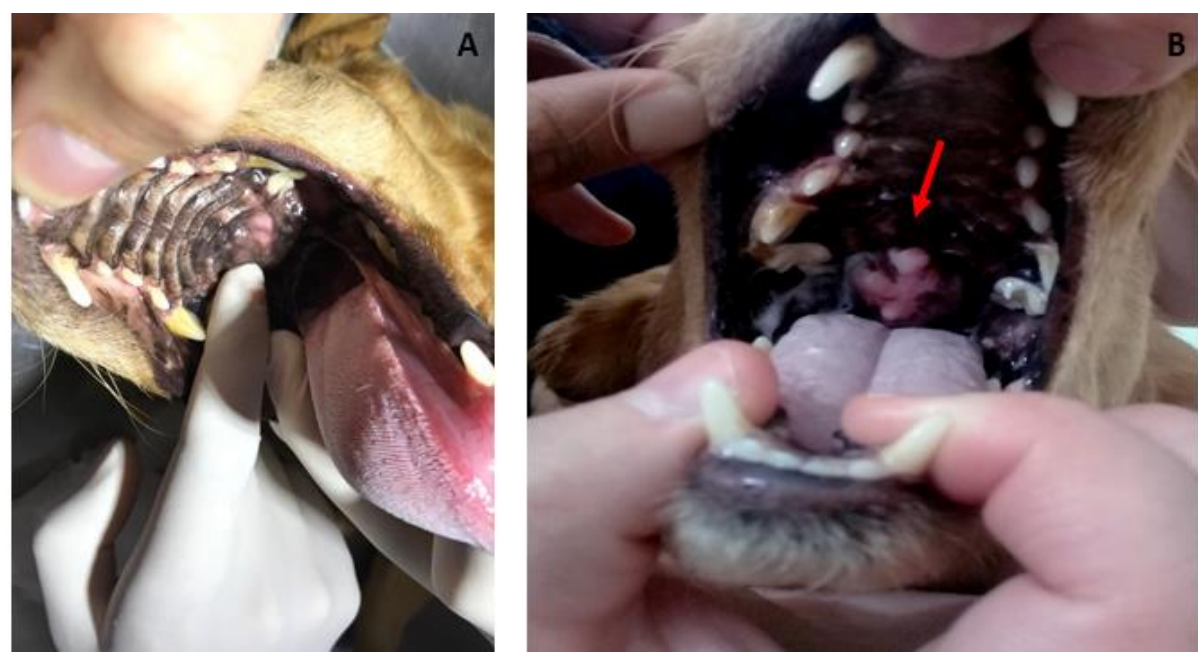

Figure 1. Six year old female mongrel dog presenting tumor in the hard palate (indicated by the arrow). 

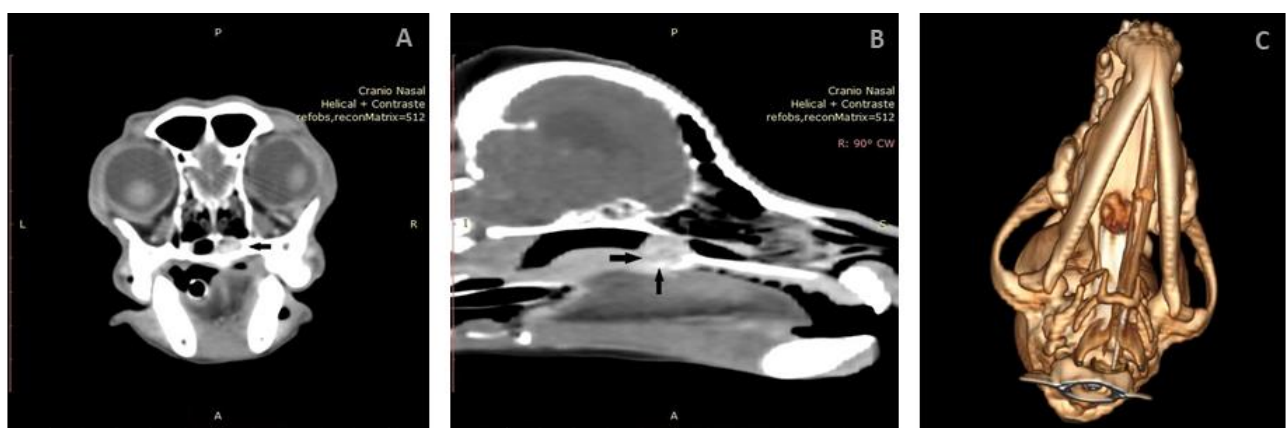

Figure 2. Computed tomography sections (A and B) show expansive formation with rounded shape on hard palate. 3D image reconstruction $(\mathrm{C})$ demonstrating expansive mass in the hard palate region $(1.2 \mathrm{x} 1.7 \mathrm{x}$ $1.6 \mathrm{~cm}$ around).
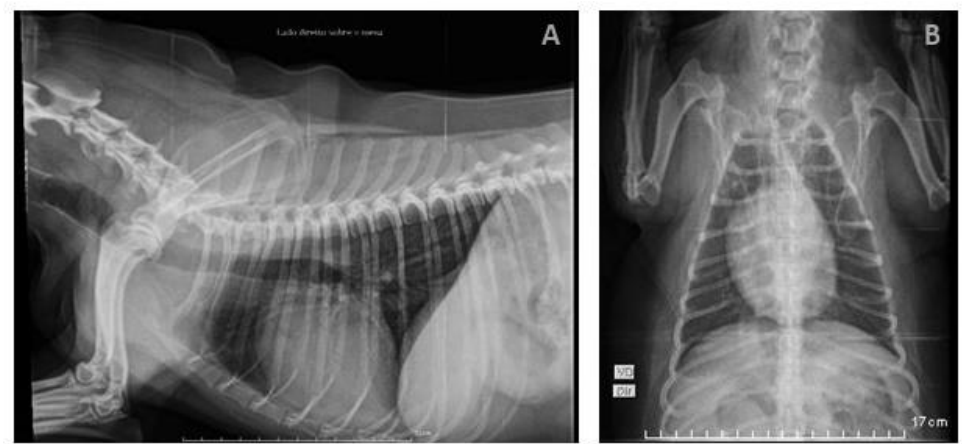

Figure 3. Thoracic radiographs (A and B) without evidence of metastasis in lung parenchyma.

Considering the lesion size and the severity of clinical presentation, tumoral exeresis was only partially performed. The tumoral mass was sent to the Laboratory of Comparative Pathology (LPC) ICB/UFMG for histopathological diagnosis. The histological examination of the mass $(1.2 \times 0.9 \times$ $0.5 \mathrm{~cm}$ ), stained with the Hematoxylin and Eosin technique, revealed individualized oval to spindle-shaped pleomorphic mesenchymal cells exhibiting many criteria of malignancy such as marked pleomorphism, hyperchromatism, anisocytosis, anisokaryosis and low mitotic index, with the production of an osteoid matrix, presenting a chondroblastic pattern (Figure 4A and $\mathrm{B}$ ).

In order to better characterize the tumor, immunohistochemistry was done in sections of neoplastic tissue. Briefly, consecutive $3 \mu \mathrm{m}$ - thick sections of primary tumor were cut and mounted on common slides for immunohistochemical (IHC) analysis, and the antigen was immunodetected using the detection system antimouse/anti-rabbit (Novolink Polymer Detection System, Leica Biosystems, Newcastle Upon Tyne, United Kingdom) according to the manufacturer's instructions. Endogenous peroxidase activity was blocked with a $10 \%$ hydrogen peroxide (H2O2) solution in methyl alcohol. Reagents were manually applied and immunoreactivity was visualized by incubating the slides with the chromogen diaminobenzidine (DAB Substrate System, Dako, Carpinteria, CA, USA) for 3 minutes (Auler et al., 2014), with some modifications. Details of the antibodies, dilutions, antigen retrieval procedures, and incubation times used in the immunostaining process are shown in Table 1.

The proliferative index was calculated by counting the number of Ki-67 positively labelled nuclei in a total of 1000 neoplastic cells. KI-67 expression was present in $30 \%$ of the neoplastic cells (Figure 4D). S100 has been associated with chondroblastic differentiation of sarcoma (Mandal et al., 2014). The neoplastic cells were positive for S100 (Figure 4E). COX-2 expression has been associated with poor prognosis and a shorter survival time in dogs with appendicular OSA (Mullins et al., 2004). COX-2 expression evaluation was semi-quantitative, and the distribution score defined by the estimated 
percentage of positive cells in five fields $(400 \mathrm{x}$ magnification): zero $=$ absence; $1=$ fewer than $10 \%$ stained cells; $2=$ between $10 \%$ and $30 \% ; 3=$ between $31 \%$ and $60 \% ; 4=$ more than $61 \%$ stained cells. For staining intensity, values from 0 to 3 were attributed: 0 = absence, $1=$ weak staining, 2 = moderate staining and $3=$ strong staining (Lavalle et al., 2012). In this case the neoplastic epithelial cells showed weak intensity of staining for COX-2. (Figure 4F).

Table 1. Antibodies and clones, manufacturer, dilutions, antigen retrieval methods, and incubation times for IHC staining for Ki-67, COX-2 and S100

\begin{tabular}{|c|c|c|c|c|c|c|}
\hline Antibody & Clone & Manufacturer & Dilution & AR Method & $\begin{array}{c}\text { Retrieval } \\
\text { solution }(\mathrm{pH})\end{array}$ & Incubation time \\
\hline Cox-2 & SP21 & $\begin{array}{l}\text { Thermo } \\
\text { Fisher }\end{array}$ & $1: 10$ & $\begin{array}{c}\text { Pressurized } \\
\text { heating }\left(125^{\circ} \mathrm{C}\right)\end{array}$ & Citrate (6.0) & $\begin{array}{l}\text { overnight } \\
\text { (18hrs) }\end{array}$ \\
\hline Ki67 & Mib & Dako & $1: 50$ & $\begin{array}{c}\text { Pressurized } \\
\text { heating }\left(125^{\circ} \mathrm{C}\right)\end{array}$ & Citrate (6.0) & $\begin{array}{l}\text { overnight } \\
\text { (18hrs) }\end{array}$ \\
\hline $\mathrm{S} 100$ & Polyclonal & Dako & $1: 100$ & $\begin{array}{c}\text { Pressurized } \\
\text { heating }\left(125^{\circ} \mathrm{C}\right)\end{array}$ & Citrate (6.0) & $\begin{array}{l}\text { overnight } \\
\text { (18hrs) }\end{array}$ \\
\hline
\end{tabular}
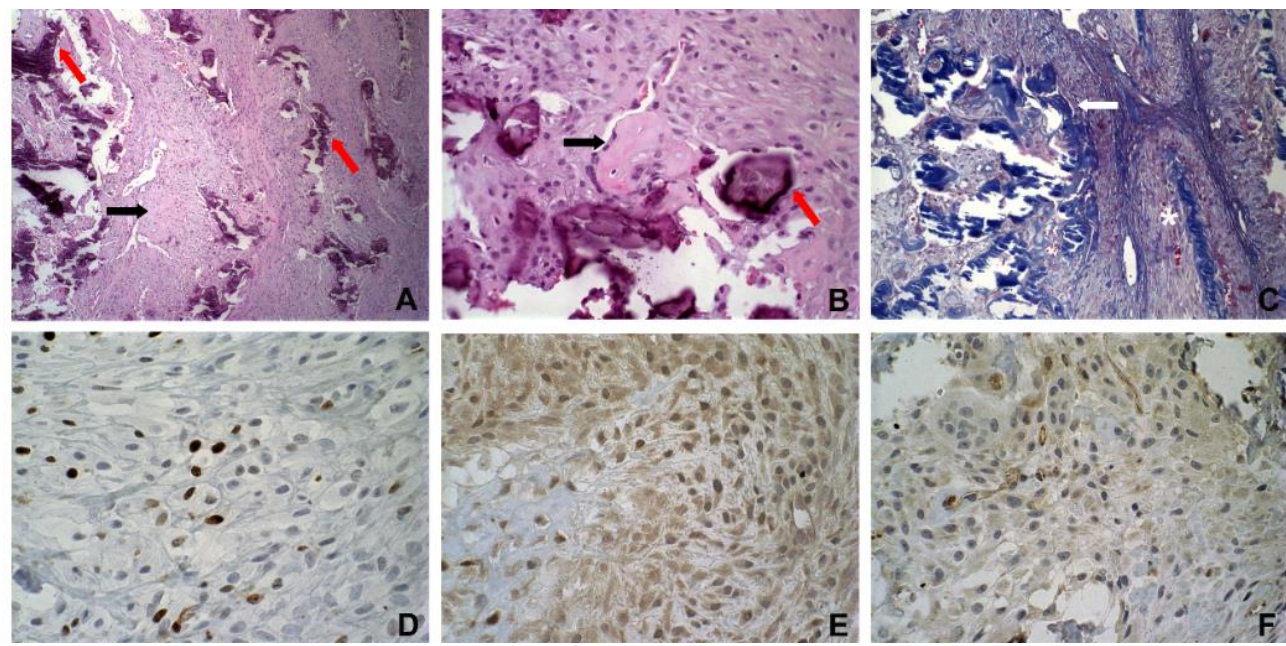

Figure 4. Photomicrographs illustrating the histological and immunohistochemical (IHC) features of canine osteosarcoma (OSA). A and B: OSA of chondroblastic pattern. The predominance of areas with cells showing marked pleomorphism, hyperchromatic nuclei and with focal osteoid matrix. Focal osteoid matrix (black arrow). Areas of mineralization (red arrow). (H\&E stain. 10x and 40x, respectively). C: The Masson's trichrome staining was also used for the evaluation of connective tissue. Areas of mineralization (white arrow). Collagen fibers (white asterisk). (Masson's trichrome stain. 20x). D: Canine OSA shows nuclear staining for KI-67 in 30\% of tumor cells (high proliferation index). (IHC 60x). E: Malignant neoplasm positive for S100. (IHC 60x). F: Neoplastic cells with a weak intensity of staining for COX-2. (IHC 60x).

The histopathology confirmed the presence of OSA in the hard palate. Therefore, conventional chemotherapy combined with metronomic chemotherapy was proposed (Dernell et al., 2007). Conventional chemotherapy was performed with four sessions of carboplatin $\left(300 \mathrm{mg} / \mathrm{m}^{2}\right)$ at 21 -day intervals. Metronomic chemotherapy was based on the administration of piroxicam $(0.3 \mathrm{mg} / \mathrm{kg}) \quad$ intercalated with cyclophosphamide $\left(15 \mathrm{mg} / \mathrm{m}^{2}\right)$. Eleven days after discharge, the patient presented edema in the thoracic limbs, increased mass in the hard palate, weight loss, along with walking, eating and sleeping problems. Clinical examination revealed halitosis, normal breathing pattern, heart rate of 120 beats per minute, and a rectal temperature of $38.7^{\circ} \mathrm{C}$. Sixty-six days after the first consultation, the patient died presenting symptoms of breathing difficulties and vomiting. Necropsy showed no evidence of pulmonary metastasis. 


\section{DISCUSSION}

The female canine was six years old, corroborating studies that have shown that OSA mainly affects adult females (Cavalcanti et al., 2004; Heyman et al., 1992; Kleiner and Silva, 2003). Large and giant breeds are most often affected by OSA (Spodnick et al., 1992), unlike the patient reported who was small and weighed less than $9 \mathrm{~kg}$. Increased alkaline phosphatase activity may be a remarkable indicator of poor prognosis for this cancer (Ziliotto et al., 2003), corroborating our findings. Appendicular OSA is highly metastatic, mainly towards the lungs. On the other hand, OSA in the axial skeleton shows a lower occurrence of metastatic spread (Heyman et al., 1992). Thoracic radiographs showed no abnormalities. However, subclinical micrometastases may be present since the start of the cancer and are not always detected by radiographs of the lungs (Cavalcanti et al., 2004).

In the present case report, the presumptive diagnosis of OSA was based on clinical history, physical examination, and CT findings. Upon examination and anamnesis, sinusitis was considered with differential diagnosis. However, CT findings demonstrated an amorphous and active new bone formation, leading to a presumptive diagnosis of OS. In this case, the sinusitis is secondary to tumor blockage in the nasal cavity that avoids drainage of the sinuses to the middle nasal meatus (Castro et al., 2013). Advanced imaging such as CT-Scan has been demonstrated to play an important role in evaluating the extent of tumor for surgical planning. The definitive diagnosis was made through histopathological examination. At the end of the diagnosis, immunohistochemistry was performed to the characterization of the tumor.

The diagnosis was validated by the gold standard test for neoplasm, which was histopathology. OSA is a malignant mesenchymal tumor of primitive bone cells, characterized by the production of osteoid tissue (Bane et al., 1990). Axial OSA is locally aggressive, it can invade into surrounding tissues and causes calcification (Dernell et al., 2007). There are different histological subtypes for this neoplasm, based on the morphological findings and the type and quantity of osteoid matrix: fibroblastic, osteoblastic, chondroblastic, giant cell type, telangiectatic and combined type when different histological patterns are present (Cavalcanti et al., 2004). In this work, the histopathological aspects of the neoplasm were compatible with the classification of chondroblastic OSA. This histological type shows the differentiation of mesenchymal cells in neoplastic chondrocytes, presence of chondroid tissue with hyaline matrix or myxoid aspect, and scarce areas of osteogenesis. Chondroblastic OSA has a high rate of metastasis than the other subtypes in dogs (Dernell et al., 2007; Esmaili Nejad et al., 2019).

In some canine tumors, the frequency of $\mathrm{Ki}-67$ proliferation index expression by neoplastic cells is significantly associated with unfavorable prognosis (Labelle et al., 2004; Peña et al., 1998; Scase et al., 2006). In this work, the cellular proliferation index was $30 \%$. S100 protein was found to be positive in this case report. S100 is sensitive but not specific for the demonstration of chondroblastic differentiation of OSA (Mandal et $a l ., 2014)$. The neoplastic cells in the tumor mass also showed weak staining for COX-2. Different human and canine bone tumors show weak to moderate COX-2 staining (Mullins et al., 2004).

The association of surgery treatment with chemotherapy has been related to a long-term survival of dogs with OSA (Beck and Strizek, 1999; Bergman et al., 1996). However, this combination is indicated more often for the treatment of canine appendicular OSA (Shapiro et al., 1988). Beck and Strizek (1999) reported a canine, male, Labrador, eight years old with OSA of the hard palate treated by tumor excision (surgery) and adjunctive chemotherapy with carboplatin. The patient presented with a twomonth history of an upper airway noise, as well as the canine reported by us in this case. Clinical examination revealed an ulcerated area $(1 \mathrm{~cm}$ in diameter) in the center of the patient's hard palate.

Considering the tumor size in this case, tumoral exeresis was performed with surgical margins. Thirty-three months after surgery the patient had no evidence of local recurrence or metastasis of the tumor. On the other hand, in our case report the patient did not have the recommendation for surgical excision of the tumor, because it was highly invasive and the resection of at least $1 \mathrm{~cm}$ of healthy tissue around the tumor is advised to minimize the risk of local recurrence (Straw et al., 1996), added to the fact that defects in the hard 
palate can be difficult to repair and reconstruct after radical surgery.

Despite the long postoperative disease-free period in the case reported by Beck and Strizek (1999), the literature reports that regardless of the treatment used for canine OSA, the estimated survival time of $6-12$ months. About $80 \%$ of the patients with axial skeleton OSA die or are euthanized by problems associated with the primary bone tumor, at six months after diagnosis (Heyman et al., 1992), corroborating our findings. In summary, this case report describes the clinicopathological and immunohistochemical features of an unusual case of OSA of the hard palate and reinforces that the diagnosis of the neoplasm is important especially in early stages for improving prognosis.

\section{ACKNOWLEDGEMENTS}

This work was supported in part by Conselho Nacional de Desenvolvimento Científico e Tecnológico (CNPq)".

\section{REFERENCES}

AULER, P.A.; GAMBA, C.O.; HORTA, R.S. et al. Metastatic well differentiated squamous cell carcinoma in the prepuce of a dog: a report of clinicopathological, immunophenotypic and therapeutic approach. Arq. Bras. Med. Vet. Zootec., v.66, p.1317-1322, 2014.

BANE, B.L.; EVANS, H.L.; RO, J.Y. et al. Extraskeletal osteosarcoma. A clinicopathologic review of 26 cases. Cancer, v.66, p.762-770, 1990.

BECK, J.A.; STRIZEK, A.A. Full-thickness resection of the hard palate for treatment of osteosarcoma in a dog. Aust. Vet. J., v.77, p.163$165,1999$.

BERGMAN, P.J.; MACEWEN, E.G.; KURZMAN, I.D. et al. Amputation and carboplatin for treatment of dogs with osteosarcoma: 48 cases (1991 to 1993). J. Vet. Inter. Med., v.10, p.76-81, 1996.

CASTRO, J.L.C.; SANTALUCIA, S.; NAZARETH, W. et al. Axial osteosarcoma in dog - case report. J. Vet. Adv., v.3, p.29-33, 2013.
CAVALCANTI, J.N.; AMSTALDEN, E.M.I.; GUERRA, J.L.; MAGNA, L.C. Osteosarcoma in dogs: clinical-morphological study and prognostic correlation. Braz. J. Vet. Res. Anim. Sci., v.41, p.299-305, 2004.

DERNELL, W.S.; STRAW R.C.; WITHROW S.J. et al. Tumors of the skeletal system. In: WITHRAW, S.; VAIL, D. Withrow and MacEwen's small animal clinical oncology. 4.ed. St. Louis, USA: Saunders Elsevier, 2007. p.540582.

DIAMOND, S.S.; RAFLO, C.P.; ANDERSON, M.P. Multilobular osteosarcoma in the dog. Vet. Pathol., v.17, p.759-763, 1980.

ESMAILI NEJAD, M.R.; VAFAEI, R.; MASOUDIFARD, M. et al. Aggressive chondroblastic osteosarcoma in a dog: a case report. Vet. Res. Forum, v.10, p.361-364, 2019.

HEYMAN, S.J.; DIEFENDERFER, D.L.; GOLDSCHMIDT, M.H.; NEWTON, C.D. Canine axial skeletal osteosarcoma a retrospective study of 116 cases (1986 to 1989). Vet. Surg., v.21, p.304-310, 1992.

HOWARD， D.R.; LAMMERDING， J.J.; MERKLEY, D.F.; BLOOMBERG, M.S. Osteosarcoma of the hard palate in a dog. Vet. Med. Small Anim. Clin., v.71, p.59-61, 1976.

KLEINER, J.A.; SILVA, E.G. Tumores ósseos em pequenos animais. Rev. MedVep., v.1, p.2133, 2003.

LABELLE, P.L.; FARVRT, T.B.; KYLES, A.E. et al. Indicators of malignancy of canine adrenocortical tumors: histopathology and proliferation index. Vet. Pathol., v.41, p.490-497, 2004.

LAVALLE, G.E.; CAMPOS, C.B.; BERTAGNOLLI, A.C.; CASSALI, G.D. Canine malignant mammary gland neoplasms with advanced clinical staging treated with carboplatin and cyclooxygenase inhibitors. In vivo, v.26, p.375-380, 2012.

MANDAL, P.K.; CHATTERJEE, S.; RAY, S. et al. Osteosarcoma: an immunophenotypic study for characterization and behavior. Bangladesh J. Med. Sci., v.13, p.443-448, 2014.

MULLINS, M.N.; LANA, A.E.; DERNELL, W.S. et al. Cyclooxygenase-2 expression in canine appendicular osteosarcomas. J. Vet. Intern. Med., v.18, p.859-865, 2004. 
PEÑA, L.L.; NIETO, A.I.; PÉREZ-ALENZA, D. et al. Immunohistochemical detection of Ki-67 and PCNA in canine mammary tumors: relationship to clinical and pathologic variables. $J$. Vet. Diagn. Invest., v.10, p.237-246, 1998.

SCASE, T.J.; EDWARDS, D.; MILLER, J. et al. Canine mast cell tumors: correlation of apoptosis and proliferation markers with prognosis. J. Vet. Intern. Med., v.20, p.151-158, 2006.

SHAPIRO, W.; FOSSUM, T.W.; KITCHELL, B.E. et al. Use of cisplatin for treatment of appendicular osteosarcoma in dogs. J. Am. Vet. Med. Assoc., v.192, p.507-511, 1988.

SPODNICK, G.J.; SELVARAJAH, G.T.; NIELEN, M.; KIRPENSTEIJN, J. Prognosis for dogs with appendicular osteosarcoma treated by amputation alone: 162 cases (1978-1988). J. Am. Vet. Med. Assoc., v.200, p.995-999, 1992.
STRAW, R.C.; POWERS, B.E.; KLAUSNER, J. et al. Canine mandibular osteosarcoma: 51 cases (1980-1992). J. Am. Anim. Hosp. Assoc., v.32, p.257-262, 1996.

WITTIG, J.C.; BICKELS, J.; PRIEBAT, D. et al. Osteosarcoma: a multidisciplinary approach to diagnosis and treatment. Am. Fam. Physician, v.65, p.1123-1132, 2002.

ZILIOTTO, L.; DALECK, C.R.; PADILHA FILHO, J.G. et al. Utilização de implante ósseo cortical alógeno conservado em glicerina para preservação de membro torácico: estudo experimental em cães. Acta Bras. Cir., v.18, p.107-115, 2003. 